\title{
Novel applications of the hypervalent iodine chemistry. Synthesis of thiazolo-fused quinolinones
}

\author{
M. Teresa Herrero, Imanol Tellitu, Susana Hernández, \\ Esther Domínguez,* Isabel Moreno, and Raúl SanMartín \\ Departamento de Química Orgánica II, Facultad de Ciencias, Universidad del País Vasco - \\ Euskal Herriko Unibertsitatea, Apdo. 644-48080 Bilbao, Spain \\ E-mail: qopdopee@lg.ehu.es
}

\section{Dedicated to Professor Marcial Moreno-Manas on his $6^{\text {th }}$ anniversary \\ (received 16 Nov 01; accepted 28 Jan 02; published on the web 05 Feb 02)}

\begin{abstract}
A synthesis of thiazolo[5,4-c]quinolinone derivatives featuring the use of two different hypervalent iodine reagents has been achieved starting from ethyl benzoylacetate in an efficient way. Hydroxy(tosyloxy)phenyliodine (HITB, Koser's reagent) has been employed to functionalize the starting $\beta$-ketoester $\mathbf{4}$, and phenyliodine(III)bis(trifluoroacetate) (PIFA) to perform a ring closure reaction on the corresponding $N$-methoxyamides 9 and 14.
\end{abstract}

Keywords: Hypervalent iodine, PIFA; HITB, quinoline, thiazole, cyclization

\section{Introduction}

In recent years our group has been concerned with the development of the hypervalent iodine chemistry. In particular, we have reported the superior behavior of PIFA as a biaryl coupling reagent, over other metallic oxidants, in the preparation of polycyclic heterocycles such as phenanthrenes, ${ }^{1}$ phenanthrenoids ${ }^{2}$ and benzo[c]phenanthridines. ${ }^{3}$ The clean transformations achieved, the mild conditions employed, and the low toxicity associated to it, prompted us to include PIFA in our synthetic plans.

Thus, we next focused our attention in the known ability of PIFA to generate $N$ acylnitrenium ions from $N$-alkoxyamides ${ }^{4}$ which, eventually, could be trapped, intramolecularly in our case, by arene rings to afford the quinoline skeleton in a simple way (see Scheme 1). 
<smiles>[R]ON([AlH])C([R])=O</smiles>

\section{Scheme 1}

In this context, we considered that the pharmacological versatility of quinoline derivatives 5 could be modified, or even enhanced, in their heterocycle-fused analogues. ${ }^{6}$ In fact, the synthesis and the activity of a number of natural products with fused quinoline heterocyclic skeletons have been reported. ${ }^{7}$ In particular, we considered that the thiazole moiety, which is present in a number of important natural products (epothilone, ${ }^{8}$ althiomycin, ${ }^{9}$ bistramide $\mathrm{C}^{10}{ }^{10}$ sulfomycin $\mathrm{I}^{11}$ ), in antibiotics (cystothiazole ${ }^{12}$ ) and, notably, in thiamine (vitamin B) inter alia, would be an interesting and promising substructure to be included in our target molecules. ${ }^{13}$

Thus, in this paper we want to show a simple and efficient synthesis of thiazolo[5,4c]quinolin-4-ones of type $\mathbf{1}$ from $\beta$-ketoesters $\mathbf{3}$ following the retrosynthetic analysis depicted in Scheme 2.<smiles>[X]c1nc2c(s1)c(=O)n([R])c1ccccc21</smiles>

1<smiles>[X]c1nc(-c2ccccc2)c(C(=O)NOC)s1</smiles>

2

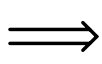<smiles>[R]OC(=O)CC(=O)c1ccccc1</smiles>

3

\section{Scheme 2}

\section{Results and Discussion}

The construction of the substituted thiazole ring started, as shown in Scheme 3, with the HITBmediated oxytosylation of commercially available $\beta$-ketoester $\mathbf{4}^{14}$ followed by application of the Hantzsch conditions on the resulting ester 5. $\alpha$-Tosyloxy substituted ketones, as 5, have encountered a wide application in organic synthesis as alternative precursors to the corresponding halo-derivatives but without their unpleasant lachrymose properties. ${ }^{15}$ Thus, heating ester 5 in DMF in the presence of thioacetamide or thiobenzamide afforded thiazoles 6 and 11, respectively, in very good yields (see Scheme 3). 


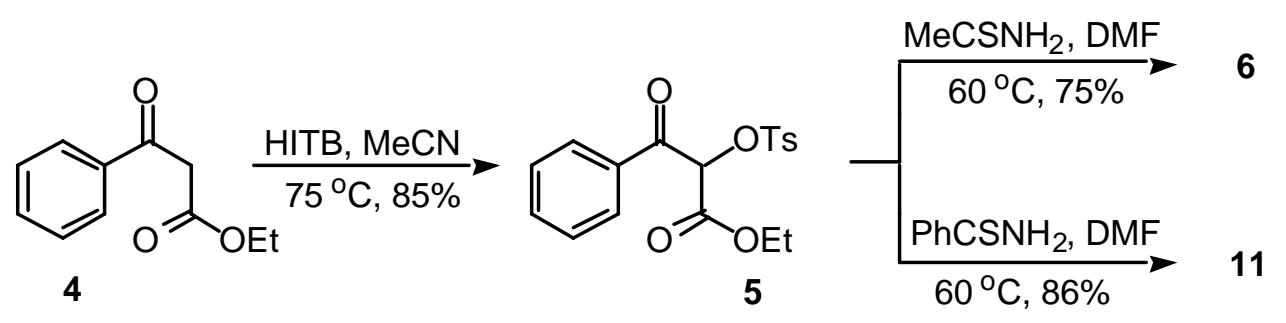

\section{Scheme 3}

At this point (see Scheme 4), basic hydrolysis of the ester groups and subsequent activation of the resulting free carboxylic acids $\mathbf{7}$ and $\mathbf{1 2}$ with thionyl chloride afforded the corresponding acyl chlorides $\mathbf{8}$ and $\mathbf{1 3}$ which, without isolation, were treated following standard procedures with methoxylamine to yield the required $N$-methoxyamides $\mathbf{9}$ and 14, respectively. Kikugawa had previously employed this kind of precursor in an electrophilic aromatic substitution reaction, which involved a $\mathrm{N}$-chlorination step with t-BuOCl and oxidative cyclization using silver or zinc salts. ${ }^{16}$ Similarly, Cherest and Lusinchi employed ferric chloride with the same purpose. ${ }^{17}$ Later, it was found ${ }^{4}$ that limitations associated with these protocols (i. e. solubility of silver salts or undesired aromatic chlorination) could be overcome by using PIFA as the cyclization reagent in a single step. Following this strategy, the prepared amides $\mathbf{9}$ and $\mathbf{1 4}$ were treated with the cyclization reagent under optimized experimental conditions to afford the desired thiazoloquinolinones 10 and 15 in 90\% and 97\% yield, respectively. The same products were obtained when TFA was employed as an alternative to boron trifluoride but with lower yields and longer reaction times. 

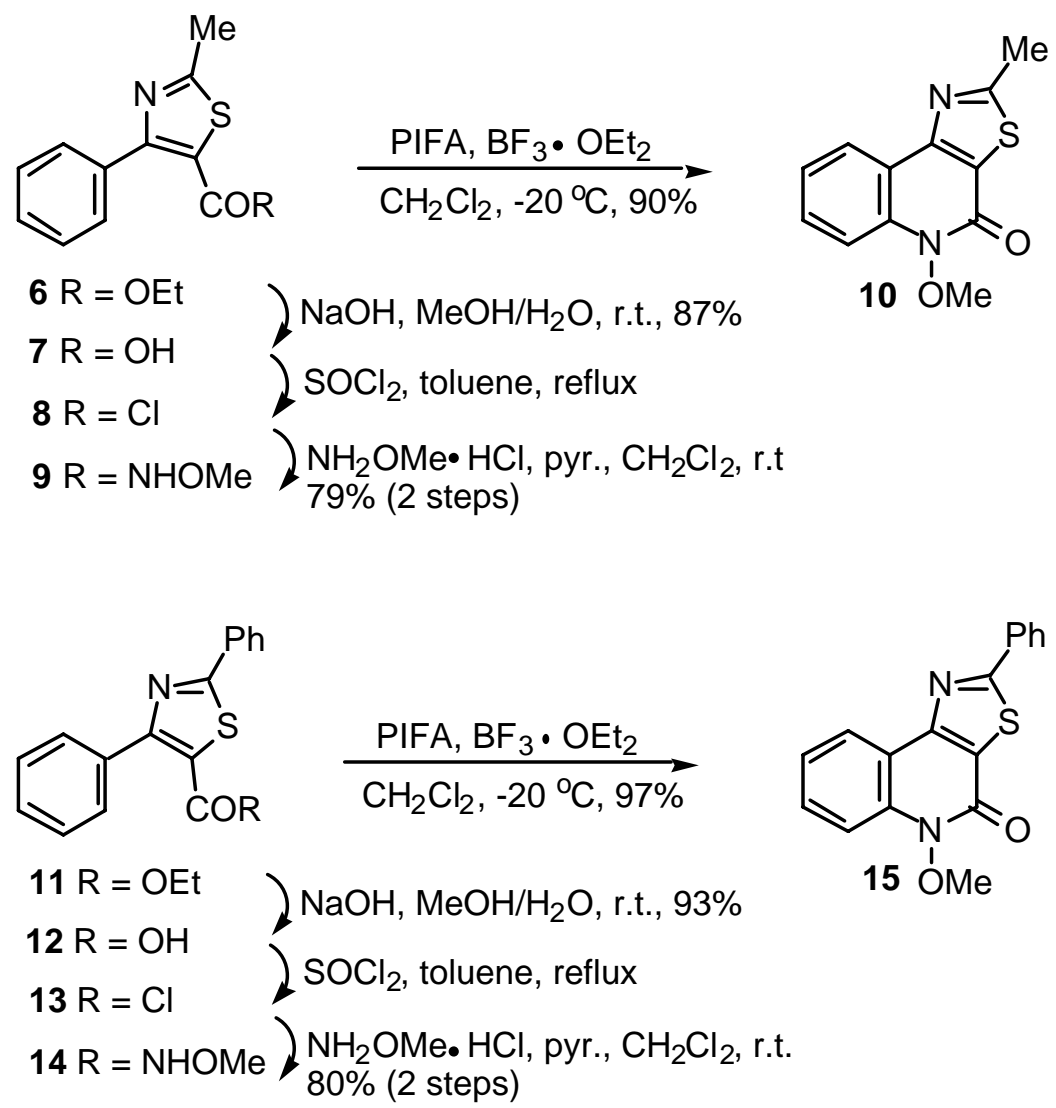

\section{Scheme 4}

In conclusion, the iodine (III)-mediated preparation of thiazolo[5,4-c]quinolin-4-ones has been described. The validity of the employed protocol in the synthesis of other quinolinone fused heterocycles, as well as the scope of substituents in the aromatic moiety of the quinolinone nucleus ring is currently under study.

\section{Experimental Section ${ }^{18}$}

Typical procedure for the Hantzsch cyclization. Synthesis of 5-ethoxycarbonyl-2-methyl-4phenylthiazole (6)

A solution of ester $5^{14}(1 \mathrm{~g}, 2.76 \mathrm{mmol})$ and thioacetamide $(0.31 \mathrm{~g}, 4.14 \mathrm{mmol})$ in DMF (10 mL) was stirred at $60{ }^{\circ} \mathrm{C}$ for $24 \mathrm{~h}$ (48 h for 11). After reaching rt, EtOAc (20 mL) was added and washed with $\mathrm{H}_{2} \mathrm{O}$ (3x10 mL). The aqueous layer was dried over $\mathrm{Na}_{2} \mathrm{SO}_{4}$, filtered and the solvent was evaporated under vacuum. The resulting mixture was column chromatographed (Hex/AcOEt, 8/2) to afford an oil which was crystallized from hexanes (75\%). mp 32-35 ${ }^{\circ} \mathrm{C}$ (Hexanes); ${ }^{1} \mathrm{H}-\mathrm{NMR}\left(\mathrm{CDCl}_{3}\right) 1.26$ (t, $\left.J=7.1,3 \mathrm{H}, \mathrm{CH}_{2}-\mathrm{CH}_{3}\right), 2.73$ (s, 3H, $\mathrm{CH}_{3}$ ), 4.25 (q, $J=7.1$, 2H, $\mathrm{CH}_{2}$ ), 7.41-7-43 (m, 3H, $\mathrm{H}_{\text {arom }}$ ), 7.70-7.73 (m, $2 \mathrm{H}, \mathrm{H}_{\text {arom }}$ ); ${ }^{13} \mathrm{C}-\mathrm{NMR}\left(\mathrm{CDCl}_{3}\right)$ 13.7, 19.0, 
60.9, 122.0, 127.3, 128.6, 129.4, 133.7, 159.3, 160.9, 168.5; IR (KBr) $1721 \mathrm{~cm}^{-1}$. Anal. Calcd for $\mathrm{C}_{13} \mathrm{H}_{13} \mathrm{NO}_{2} \mathrm{~S}$ : C, 63.13; H, 5.30; N, 5.66. Found: C, 63.33; H, 5.59; N, 5.40.

2,4-Diphenyl-5-ethoxycarbonylthiazole (11). According to the typical procedure thiazole 11 was obtained from ester 5 in $86 \%$ yield as a yellowish solid. mp $103-105{ }^{\circ} \mathrm{C}\left(\mathrm{Et}_{2} \mathrm{O}\right)$; ${ }^{1} \mathrm{H}-\mathrm{NMR}$ $\left(\mathrm{CDCl}_{3}\right) 1.33$ (t, $\left.J=7.1,3 \mathrm{H}, \mathrm{CH}_{2}-\underline{\mathrm{C}}_{3}\right), 4.32$ (q, $\left.J=7.1,2 \mathrm{H}, \mathrm{CH}_{2}\right), 7.46-7.50$ (m, 6H, $\mathrm{H}_{\text {arom}}$ ), 7.86-7.90 (m, 2H, $\mathrm{H}_{\text {arom }}$ ), 8.04-8.08 (m, $\left.2 \mathrm{H}, \mathrm{H}_{\text {arom }}\right) ;{ }^{13} \mathrm{C}-\mathrm{NMR}\left(\mathrm{CDCl}_{3}\right)$ 14.0, 61.4, 122.2, 126.7, 127.6, 128.9, 129.0, 129.8, 131.0, 132.7, 134.0, 160.6, 161.4, 169.6; IR (KBr) $1721 \mathrm{~cm}^{-1}$. Anal. Calcd for $\mathrm{C}_{18} \mathrm{H}_{15} \mathrm{NO}_{2} \mathrm{~S}$ : C, 69.88; H, 4.89; N, 4.53. Found: C, 69.63; H, 4.59; N, 4.33.

Typical procedure for the hydrolysis of esters 6 and 11. Synthesis of 5-carboxy-2-methyl-4phenylthiazole (7)

Over a solution of ester 6 (0.53 g, $2.14 \mathrm{mmol})$ in $\mathrm{MeOH}(20 \mathrm{~mL}), \mathrm{NaOH}(0.52 \mathrm{~g}, 13 \mathrm{mmol})$ and 2-5 mL of water was added. The mixture was stirred at rt until total consumption of the starting material $(1 \mathrm{~d})$. Then, $\mathrm{HCl}$ (5\% ac.) was added and the mixture was extracted with EtOAc ( $3 \mathrm{x}$ $10 \mathrm{~mL}$ ). The aqueous layer was dried over $\mathrm{Na}_{2} \mathrm{SO}_{4}$, filtered and the solvent was evaporated under vacuum. The resulting mixture was column chromatographed (Hex/AcOEt, 2/8) to afford carboxylic acid 7 as a white solid which was crystallized from hexanes (87\%). mp $186-187{ }^{\circ} \mathrm{C}$ (Hexanes); ${ }^{1} \mathrm{H}-\mathrm{NMR}$ (DMSO) 2.69 (s, 3H, CH3), 7.39-7.41 (m, 3H, $\mathrm{H}_{\text {arom}}$ ), 7.69-7.70 (m, 2H, $\mathrm{H}_{\text {arom}}$ ), 11.49 (sa, 1H, COOH); ${ }^{13} \mathrm{C}-\mathrm{NMR}$ (DMSO) 19.2, 123.6, 127.8, 128.9, 130.0, 134.2, 158.2, 162.4, 168.7; IR (KBr) 3409, $1647 \mathrm{~cm}^{-1}$. Anal. Calcd for $\mathrm{C}_{11} \mathrm{H}_{9} \mathrm{NO}_{2} \mathrm{~S}$ : C, 60.26; H, 4.14; N, 6.39. Found: C, 60.33; H, 4.39; N, 6.43.

2,4-Diphenyl-5-carboxythiazole (12). According to the typical procedure carboxylic acid 12 was obtained from ester 11 in 93\% yield as a white solid. mp $202-204{ }^{\circ} \mathrm{C}(\mathrm{MeOH})$; ${ }^{1} \mathrm{H}-\mathrm{NMR}$ (DMSO) 7.44-7.47 (m, 3H, $\mathrm{H}_{\text {arom }}$ ), 7.53-7.55 (m, 3H, $\mathrm{H}_{\text {arom }}$ ), 7.78-7.82 (m, 2H, $\mathrm{H}_{\text {arom }}$ ), 8.01-8.05 (m, 2H, $\mathrm{H}_{\text {arom }}$ ), 13.49 (sa, 1H, COOH); ${ }^{13} \mathrm{C}-\mathrm{NMR}$ (DMSO) 124.0, 126.8, 127.8, 129.1, 129.5, 130.1, 131.5, 132.4, 134.2, 159.3, 162.4, 168.6; IR (KBr) 3000-2000, $1660 \mathrm{~cm}^{-1}$. Anal. Calcd for $\mathrm{C}_{16} \mathrm{H}_{11} \mathrm{NO}_{2} \mathrm{~S}$ : C, 68.31; H, 3.94; N, 4.98. Found: C, 68.53; H, 4.00; N, 4.73.

Typical procedure for the synthesis of amides 9 and 14. Synthesis of 5-( $N-$ methoxycarbamoyl)-2-methyl-4-phenylthiazole (9)

Thionyl chloride $(0.15 \mathrm{~mL}, 2.05 \mathrm{mmol})$ was added to a solution of the carboxylic acid 7 ( $0.3 \mathrm{~g}$, $1.37 \mathrm{mmol})$ in $\mathrm{CH}_{2} \mathrm{Cl}_{2}(10 \mathrm{~mL})$. The mixture was heated at reflux for $4 \mathrm{~h}$. Removal of solvent in vacuo gave the corresponding aroyl chloride $\mathbf{8}$ as a residue which, without isolation, was dissolved again in $\mathrm{CH}_{2} \mathrm{Cl}_{2}(15 \mathrm{~mL})$. To this solution, hydroxylamine ( $\mathrm{HCl}$ salt) (0.12 g, $1.51 \mathrm{mmol})$ and pyridine $(0.27 \mathrm{~mL}, 3.30 \mathrm{mmol})$ was added at $0{ }^{\circ} \mathrm{C}$, and the mixture was stirred at rt until the conversion was complete. Then, the solution was washed with saturated $\mathrm{CuSO}_{4}$, the organic layer was dried $\left(\mathrm{Na}_{2} \mathrm{SO}_{4}\right)$ and concentrated in vacuo. The residue was column chromatographed (Hex/EtOAc, 3/7) and the resulting amide 9 was crystallized from hexanes as a pale brown solid. mp $154-155{ }^{\circ} \mathrm{C}$ (Hexanes); ${ }^{1} \mathrm{H}-\mathrm{NMR}\left(\mathrm{CDCl}_{3}\right) 2.74$ (s, 3H, $\left.\mathrm{CH}_{3}\right), 3.72$ (s, 3H, $\mathrm{OCH}_{3}$ ), 7.47-7.51 (m, 3H, $\mathrm{H}_{\text {arom }}$ ), 7.59-7.65 (m, 2H, $\left.\mathrm{H}_{\text {arom }}\right), 8.15$ (s, $\left.1 \mathrm{H}, \mathrm{NH}\right) ;{ }^{13} \mathrm{C}-\mathrm{NMR}\left(\mathrm{CDCl}_{3}\right)$ 
19.2, 64.2, 128.8, 129.4, 124.8, 133.4, 154.3, 160.1, 168.2; IR (KBr) 3113, $1670 \mathrm{~cm}^{-1}$. Anal. Calcd for $\mathrm{C}_{12} \mathrm{H}_{12} \mathrm{~N}_{2} \mathrm{O}_{2} \mathrm{~S}$ : C, 58.05; H, 4.87; N, 11.28. Found: C, 58.26; H, 4.69; N, 11.43.

2,4-Diphenyl-5-( $N$-methoxycarbamoyl)thiazole (14). According to the typical procedure amide 14 was obtained from acid 12 in $80 \%$ yield as a pale brown solid. mp ${ }^{145}-147{ }^{\circ} \mathrm{C}\left(\mathrm{Et}_{2} \mathrm{O}\right) ;{ }^{1} \mathrm{H}-$ NMR $\left(\mathrm{CDCl}_{3}\right) 3.72$ (s, 3H, $\left.\mathrm{OCH}_{3}\right), 7.40-7.53$ (m, 6H, $\mathrm{H}_{\text {arom }}$ ), 7.69-7.71 (m, 2H, $\mathrm{H}_{\text {arom }}$ ), 7.94-8.00 (m, 2H, $\mathrm{H}_{\text {arom }}$ ), 8.47 (sa, $\left.1 \mathrm{H}, \mathrm{NH}\right) ;{ }^{13} \mathrm{C}-\mathrm{NMR}\left(\mathrm{CDCl}_{3}\right)$ 64.3, 124.9, 126.7, 128.9, 129.6, 130.9, 132.5, 133.6, 155.4, 160.2, 169.4; IR (KBr) 3158, $1662 \mathrm{~cm}^{-1}$. Anal. Calcd for $\mathrm{C}_{17} \mathrm{H}_{14} \mathrm{~N}_{2} \mathrm{O}_{2} \mathrm{~S}$ : C, 65.79; H, 4.55; N, 9.03. Found: C, 65.46; H, 4.69; N, 9.33.

Typical procedure for the cyclization of amides 9 and 14. Synthesis of $N$-methoxy-2methylthiazolo[5,4-c]quinolin-4-one (10)

A solution of PIFA (139 mg, $0.32 \mathrm{mmol})$ and $\mathrm{BF}_{3} \cdot \mathrm{OEt}_{2}(0.08 \mathrm{~mL}, 0.65 \mathrm{mmol})$ in $8 \mathrm{~mL}$ of $\mathrm{CH}_{2} \mathrm{Cl}_{2}$ was added at $-20{ }^{\circ} \mathrm{C}$ to a solution of amide 9 (53 mg, $0.21 \mathrm{mmol}$ ) in $5 \mathrm{~mL}$ of the same solvent. The mixture was stirred at the same temperature during $20 \mathrm{~min}$, washed with $10 \%$ aqueous $\mathrm{NaHCO}_{3}$ and dried over $\mathrm{Na}_{2} \mathrm{SO}_{4}$. Then, the solvent was evaporated and the residual oil was column chromatographed (Hexanes/EtOAc, 6:4) and crystallized from hexanes to afford pure quinolinone 10 (47 mg, 90\%) as a yellowish solid. mp 180-182 ${ }^{\circ} \mathrm{C}$ (Hexanes); ${ }^{1} \mathrm{H}-\mathrm{NMR}$ $\left(\mathrm{CDCl}_{3}\right) 2.91$ (s, 3H, CH$)_{3}, 4.15\left(\mathrm{~s}, 3 \mathrm{H}, \mathrm{OCH}_{3}\right), 7.37-7.44\left(\mathrm{~m}, 1 \mathrm{H}, \mathrm{H}_{\text {arom}}\right), 7.62-7.73$ (m, 2H, $\left.\mathrm{H}_{\text {arom }}\right)$, 8.40-8.43 (m, 1H, $\left.\mathrm{H}_{\text {arom }}\right)$; ${ }^{13} \mathrm{C}-\mathrm{NMR}\left(\mathrm{CDCl}_{3}\right)$ 20.2, 63.2, 112.4, 116.5, 123.3, 124.7, 130.4, 136.6, 153.5, 154.4, 173.6; IR (KBr) $1656 \mathrm{~cm}^{-1}$. Anal. Calcd for $\mathrm{C}_{12} \mathrm{H}_{10} \mathrm{~N}_{2} \mathrm{O}_{2} \mathrm{~S}$ : C, 58.52; H, 4.09; N, 11.37. Found: C, 58.73; H, 4.10; N, 11.15.

$\mathrm{N}$-Methoxy-2-phenylthiazolo[5,4-c]quinolin-4-one (15). According to the typical procedure quinolinone 15 was obtained from amide 14 in $97 \%$ yield as a white solid. mp $183-185{ }^{\circ} \mathrm{C}$ $\left(\mathrm{Et}_{2} \mathrm{O}\right) ;{ }^{1} \mathrm{H}-\mathrm{NMR}\left(\mathrm{CDCl}_{3}\right) 4.19$ (s, 3H, $\left.\mathrm{OCH}_{3}\right), 7.43$ (t, $\left.J=7.9,1 \mathrm{H}, \mathrm{H}_{\text {arom }}\right), 7.53-7.55$ (m, 3H, $\mathrm{H}_{\text {arom }}$ ), 7.64-7.75 (m, 2H, $\mathrm{H}_{\text {arom }}$ ), 8.14-8.17 (m, $2 \mathrm{H}, \mathrm{H}_{\text {arom }}$ ), 8.56 (d, J= 7.9, $1 \mathrm{H}, \mathrm{H}_{\text {arom }}$ ); ${ }^{13} \mathrm{C}-\mathrm{NMR}$ $\left(\mathrm{CDCl}_{3}\right)$ 63.2, 112.3, 116.6, 123.2, 124.5, 124.8, 127.2, 128.9, 130.3, 131.5, 132.5, 136.6, 153.5, 155.0, 174.0; IR (KBr) $1668 \mathrm{~cm}^{-1}$. Anal. Calcd for $\mathrm{C}_{17} \mathrm{H}_{12} \mathrm{~N}_{2} \mathrm{O}_{2} \mathrm{~S}$ : C, 66.22; H, 3.92; N, 9.08. Found: C, 66.33; H, 3.79; N, 9.10.

\section{Acknowledgements}

Financial support from the University of the Basque Country (UPV 170.310-G37/98) and Basque Government (PI 53/96) is gratefully acknowledged. The Ministerio de Educación y Cultura (Spain) is also acknowledged for a fellowship granted to M. T. H. and for additional financial support (PB 0600-97). 


\section{References and Notes}

1. Moreno, I.; Tellitu, I.; SanMartín, R.; Badía, D.; Carrillo, M. L.; Domínguez, E. Tetrahedron Lett. 1999, 40, 5067.

2. Moreno, I.; Tellitu, I.; SanMartín, R.; Domínguez, E. Synlett 2001, 1161.

3. Moreno, I.; Tellitu, I.; Etayo, J.; Domínguez, E.; SanMartín, R. Tetrahedron 2001, 57, 5403.

4. (a) Kikugawa, Y.; Kawase, M. Chem. Lett. 1990, 581. (b) Romero, A. G.; Darlington, W. H.; McMillan, M. W. J. Org. Chem. 1997, 62, 6582.

5. See for example: (a) Desos, P.; Lepagnol, J. M.; Morain, P.; Lestage, P.; Cordi, A. A. J. Med. Chem. 1996, 39, 197. (b) Oshiro, Y.; Sakurai, Yoji; Sato, S.; Kurahashi, N.; Tanaka, T.; Kikuchi, T.; Tottori, K.; Uwahodo, Y.; Miwa, T.; Nishi, T. J. Med. Chem. 2000, 43, 177.

6. See for example: (a) Mekheimer, R. A. Synthesis 2000, 2078. (b) Mekheimer, R. A.; Ahmed, E. K.; El-Fahham, H. A.; Kamel, L. H. Synthesis 2001, 97. and references cited therein.

7. Recent examples of natural heterocycle-fused quinolines and quinolinones can be found in: (a) Michael, J. P. Nat. Prod. Rep. 2000, 17, 603. (b) Michael, J. P. Nat. Prod. Rep. 1999, 16, 697. (c) Michael, J. P. Nat. Prod. Rep. 1997, 14, 605.

8. Nicolaou, K. C.; Finlay, M. R. V.; Ninkovic, S.; Sarabia, F. Tetrahedron 1998, 54, 7127.

9. Andrus, M. B.; Li, W.; Keyes, R. F. Tetrahedron Lett. 1998, 39, 5465.

10. Foster, M. P.; Concepción, G. P.; Caraan, G. B.; Ireland, C. M. J. Org. Chem. 1992, 57, 6671.

11. Abe, H.; Kushida, K.; Shiobara, Y.; Kodama, M. Tetrahedron Lett. 1988, 29, 1401.

12. Suzuki, Y.; Ojika, M.; Sakagami, Y.; Fudou, R.; Yamanaka, S. Tetrahedron 1998, 54, 11399.

13. The thiazolo[5,4-h]quinolin-6-one is part of the skeleton of the marine natural product kuanoniamine A. Besson, T.; Rees, C. W.; Roe, D. G.; Thiéry, V. J. Chem. Soc, Perkin Trans. 1 2000, 555.

14. Koser, G. F.; Relenyi, A. G.; Kalos, A. N.; Rebrovic, L.; Wettach, R. H. J. Org. Chem. 1982, 47, 2487.

15. (a) Prakash, O.; Saini, N.; Sharma, P. K. Synlett 1994, 221. (b) Moriarty, R. M.; Vaid, B. K.; Duncan, M. P.; Levy, S. G.; Prakash, O.; Goyal, S. Synthesis 1992, 845.

16. Kawase, M.; Kitamura, T.; Kikugawa, Y. J. Org. Chem. 1989, 54, 3394.

17. Cherest, M.; Lusinchi, X. Tetrahedron Lett. 1989, 30, 715.

18. For General Procedures, see reference 3. 